\title{
SISTEM PENDUKUNG KEPUTUSAN PEMBERIAN JUMLAH SKS MENGAJAR DOSEN PADA STMIK KAPUTAMA BINJAI
}

\author{
Akim Manaor Hara Pardede; Novriyenni \\ STMIK KAPUTAMA; Jl. Veteran No. 4A-9A, Binjai ,Sumatera Utara \\ akimmhp@live.com
}

\begin{abstract}
Abstrak
Handling the distribution of the amount of teachingcredits at the faculty is one thing that deserves to be more attention by the academic part in STMIK KAPUTAMA, thus reducing the risk of not optimal control of the implementation of learning and teaching. The distribution of the amount of teaching credits in the faculty using FuzzyLogic InferenceSystemMamdani Model to process the data so that it can produce more informed decisions, quickly and efficiently. By using Mamdani Fuzzy Logic reasoning in data processing input and output, and implemented using MATLAB Toolbox R2010a.
\end{abstract}

Key Words: Fuzzy, teaching, Mamdani,,teaching credits

\section{Pendahuluan}

\subsection{Latar Belakang}

Dosen merupakan salah satu unsur pertama dalam civitas akademika dalam sebuah perguruan tinggi (PT).

Tugas pokok, unsur dan sub unsur kegiatan dosen :

1. Tugas Pokok Dosen adalah melaksanakan pendidikan dan pengajaran pada perguruan tinggi, penelitian serta pengabdian kepada masyarakat.

2. Unsur dan Sub Unsur Kegiatan aPendidikan, meliputi:

- Pendidikan sekolah dan memperoleh ijazah/gelar.

- Mengikuti pendidikan sekolah dan memperoleh gelar/sebutan tambahan yang setingkat atau lebih tiggi di luar bidang ilmunya.

- Mengikuti pendidikan dan pelatihan fungsional Dosen serta memperoleh SuratTanda Tamat Pendidikan dan Pelatihan (STTPP) termasuk kegiatan magang sebagai Dosen yunior.

b. Tridharma Perguruan Tinggi, meliputi:

- Melaksanakan pendidikan dan pengajaran

- Melaksanakan penelitian dan pengembangan serta menghasilkan karya ilmiah, karya teknologi, karya seni monumental/seni pertunjukkan dan karya sastra.
- Melaksanakan
pengabdian
kepada.masyarakat.
c. Penunjang, meliputi:
- Menjadi anggota dalam suatu panitia/badan pada perguruan tinggi.
- Menjadi anggota panitia/badan pada lembaga pemerintah.

- Menjadi anggota organisasi profesi.

- Mewakili perguruan tinggi/lembaga pemerintah duduk dalam panitia antar lembaga.

- Menjadi anggota delegasi nasional ke pertemuan internasional.

- Berperan serta aktif dalam pertemuan ilmiah.

- Mendapat tanda jasa/penghargaan.

- Menulis buku pelajaran SLTA ke bawah.

- Mempunyai prestasi di bidang olahraga/kesenian/sosial.

Selain itu, beban kerja dosen memiliki ketentuan batas minimal dan maksimaltergantung kepada kedudukan dan jabatan dosen tersebut pada lembaga pendidikan tinggi.Seorang dosen biasa (DS) memiliki kewajiban penuh dalam beban kerjanya yaitu 12 sks

sampai dengan 16 sks dari ketiga unsur di atas.

Pada bagian akademik sering disorot banyaknya kasus dosen yang tidak memenuhi kewajibannya mengajar pada kelas yang diampunya dengan tepat waktu, ketidak sesuaian BAP terhadap SAP, dan terjadinyaketidak puasan mahasiswa dalam memperoleh penilaian maupun sikap dosen terhadap mahasiswa.

Hal ini menjadi masalah yang harus ditangani secara baik, cepat dan akurat, karenamalah ini akan selalu timbul tiap semester dalam pembagian jumlah sks yang diampu dosen,dengan adanya penanganan masalah ini, diharapkan dapat menentukan jumlah sksyang diberikan kepada dosen-dosen sesuai dengan kemampuan, kesanggupan dan profesionalis dosen bersangkutan. 


\subsection{Rumusan Masalah}

Sesuai dengan latar belakang yang telah diuraikan sebelumnya, maka rumusan masalahnyaadalah bagaimana membuat sistem pendukungkeputusan untuk penanganan pemberian jumlah sks yang tepat kepada dosen pengampu mata kulaih.

\subsection{Tujuan}

Penelitian bertujuan untuk mempermudahdalam pemantauan proses belajar dan mengajar,mempercepat pemberian informasi antar pihak terkait,pemberian jumlah sks terhadap dosen pengampu mata kuliah dengan cepat dan tepat danmemaksimalkan fungsi bagian akademik sebagai bagian dalam memantau proses belajar dan mengajar.

\section{Tinjauan Pustaka}

Penelitian yang berhubungan dengan beban kerja dosen sebelumnya sudah ada yang melakukan yaitu :

a. Rancang bangun sistem pendukung keputusan pembagian beban kerja dosen (bkd) berbasis logika fuzzy[1], permasalahan pada penelitian ini adalah beban kerja dosen (BKD) terutama untuk pembagian beban mengajar pada setiap dosen, tidak didasarkan kepada kebutuhan dan kewajiban dari dosen tersebut. Pembagian beban sering kali masih menumpuk pada dosen yang dianggap rajin saja, atau pembagiannya dibuat rata-rata tanpa memperhatikan jabatan dari dosen tersebut (DT atau DS). Di samping itu pembagian beban mengajar, belum memperhatikan latar belaknag pendidikan dan mata kuliah yang diampu sebelumnya. Sering seorang dosen berganti mata kuliah yang diampunya, padahal mata kuliah tersebut diluar bidang keahlianya, sedangkan dosen yang memiliki bidang keahlian yang sama masih memungkinkan untuk mengampu mata kuliah tersebut. Permasalahan-permasalahan tersebut akan menimbulkan pengaruh pada proses pembelajaran, seperti beban kerja dosen terlalu banyak (menumpuk), dan ada beban dosen yang terlalu sedikit. Sehingga kualitas pembelajaran juga tidak berubah sebelum dan setelah adanya sertifikasi dosen

b. Sistem pendukung keputusan dosen berprestasi yang didalamnya mencakup proses evaluasi Beban Kerja Dosen (BKD) dan pemilihan dosen berprestasi dengan menggunakan metode Promethee [2], dimana inti pembahasan pada penelitian ini adalah memanfaat BKD yang sudah dilakukan oleh dosen kemudian dievaluasi oleh tim untuk menentukan dosen berprestasi. Pada penelitian ini tidak membahas pembagian beban kerja dosen dan juga tidak menjelaskan kebutuhan beban kerja dosen untuk memenuhi kewajiban minimal dan maksimal seorang dosen terutama setelah sertifikasi dosen diperoleh.

c. Sistem Pendukung Pengambilan Keputusan Penjadwalan Kuliah Berdasarkan Preferensi Kesediaan Waktu Dosen Untuk Mengajar (Studi kasus pada STIE SBI Yogyakarta)[3], membahas tentang penjadwalan kuliah namun tidak menghubungkannya dengan batasan minimal dan maksimal dari beban mengajar yang memenuhi undang-undang. Dalam penelitian ini fokus penelitian hanya pada jadwal mengajar saja agar sesuai keinginan dosen, dan sistem yang dibangun bertujuan untuk mempermudah Jurusan/Program studi dalam menjadwal kuliah saja

d. Sistem pendukung keputusan pemilihan guru berprestasi menggunakan metode promethee[4], membahas tentang pemilihan guru prestasi yang dapat membantu untuk mendukung keputusan dalam pemilihan guru prestasi secara cepat dan akurat dengan cara memberikan alternatif pengambilan keputusan yang baik. Dalam penentuan rangking calon guru berprestasi, sistem pendukung keputusan ini menggunakan metode Promethee.

\subsection{Sistem Pendukung Keputusan (SPK)}

Sistem pendukung keputusan adalah sebuah sistem informasi berbasis komputer yang interaktif, fleksibel dan mudah beradaptasi, didesain secara khusus untuk membantu masalah managemen yang bersifat tidak terstruktur untuk memperbaiki pengambilan keputusan[3]. Secara garis besar DSS dibangun oleh tiga komponen besar: 1) Database; 2) Model Base; dan 3) Software System. Sistem database berisi kumpulan dari semua data bisnis yang dimiliki perusahaan, baik yang berasal dari transaksi sehari-hari, maupun data dasar (master file). Untuk keperluan DSS, diperlukan data yang relevan dengan permasalahan yang hendak dipecahkan melalui simulasi. Komponen kedua adalah Model Base atau suatu model yang merepresentasikan permasalahan ke dalam 
format kuantitatif (model matematika sebagai contohnya) sebagai dasar simulasi atau pengambilan keputusan, termasuk di dalamnya tujuan dari permasalahan (obyektif), komponenkomponen terkait, batasan- batasan yang ada (constraints), dan hal-hal terkait lainnya. Kedua komponen tersebut untuk selanjutnya disatukan dalam komponen ketiga (software system), setelah sebelumnya direpresentasikan dalam bentukmodel yang "dimengerti" komputer . Contohnya adalah penggunaan teknik RDBMS (Relational Database Management System), OODBMS (Object Oriented Database Management System) untuk memodelkan struktur data. Sedangkan MBMS (Model Base Management System) dipergunakan untuk merepresentasikan masalah yang ingin dicari pemecahannya. Entiti lain yang terdapat pada produk DSS baru adalah DGMS (Dialog Generation and Management System), yang merupakan suatu sistem untuk memungkinkan terjadinya "dialog" interaktif antara komputer dan manusia (user) sebagai pengambil keputusan.

\subsection{Fuzzy Logic}

Fuzzy merupakan representasi suatu pengetahuan yang dikonstruksikan dengan ifthen rules. Karakteristik dari metode ini adalah[6][7][8]:

a. Pemecahan masalah dilakukan dengan menjelaskan sistem bukan lewat angkaangka, melainkan secara linguistik, atau variabel- variabel yang mengandung ketidakpastian/ ketidaktegasan.

b. Pemakaian IF-FHEN rules untuk menjelaskan kaitan antara satu variabel dengan yang lain.

c. Menjelaskan sistem memakai algoritma fuzzy Fuzzy merupakan salah satu metode yang memiliki kelebihan-kelebihan, diantaranya[6][7][8]:

a) Dapat mengekspresikan konsep yang sulit untuk dirumuskan, seperti misalnya "suhu ruangan yang nyaman"

b) Pemakaian membership-function memungkinkan fuzzy untuk melakukan observasi obyektif terhadap nilai-nilai yang subyektif. Selanjutnya membership-function ini dapat dikombinasikan untuk membuat pengungkapan konsep yang lebih jelas.

c) Penerapan logika dalam pengambilan keputusan, memberikan hasil yang lebih baik.

Secara umum dalam sistem logika fuzzy terdapat empat buah elemen dasar, yaitu:

a. Basis kaidah (rule base), yang berisi aturan- aturan secara linguistik yang bersumber dari para pakar; b. Suatu mekanisme pengambilan keputusan (inference engine), yang memperagakan bagaimana para pakar mengambil suatu keputusan dengan menerapkan pengetahuan (knowledge);

c. Proses fuzzifikasi (fuzzification), yang mengubah besaran tegas (crisp) ke besaran fuzzy;

d. Proses defuzzifikasi (defuzzification), yang mengubah besaran fuzzy hasil dari inference engine, menjadi besaran tegas (crisp).

e. Pola masukan dihitung maju mulai dari layar masukan hingga layar keluaran menggunakan fungsi aktivasi yang ditentukan.

\section{Metode}

Penyelesaian masalah dalam menentukan jumlah sks yang akan diberikan kepada dosen pengampu mata kuliah pada Stmik Kaputama dimulai dengan menentukan input, yaitu :

A. Hasil penilain angket mahasiswa terhadap dosen (Nilai Angket).

B. Ketersediaan waktu mengajar yang diberikan dosen (Ketersediaan Waktu).

C. Kesesuain BAP dengan SAP semester sebelumnya berdasarkan penilaian Program Studi (Kesesuaian Materi)

Dan Selanjutnya menentukan output, yaitu berupa jumlah sks yang akan diberikan, yaitu :
A. $0 \mathrm{sks}$
B. 4 sks
C. 8 sks
D. $12 \mathrm{sks}$
E. $16 \mathrm{sks}$

Berikut ini ditampilkan pada saat implementasi menggunakan Matlab Toolbox pada gambar. 3.1

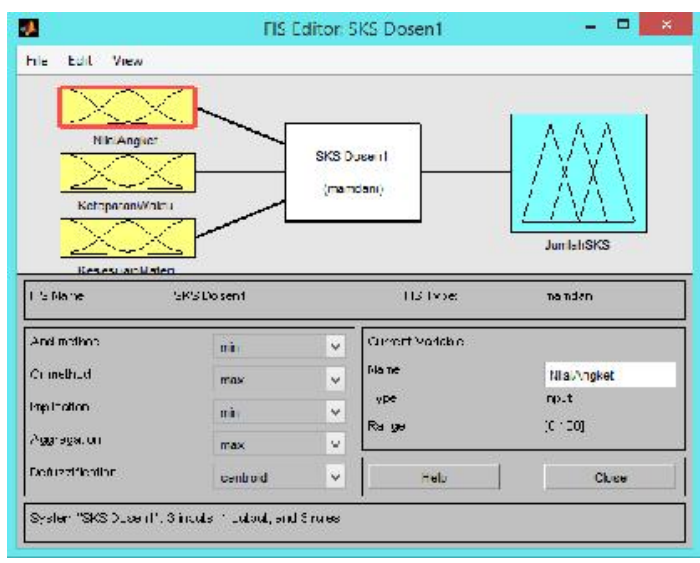

Gambar 3.1. Implementasi menggunakan Matlab Toolbox 


\subsection{Membuat himpunan dan input fuzzy}

Ada 4 variabel fuzzy yang akan dimodelkan, yaitu :

- NilaiAnket; terdiri atas 3 himpunan fuzzy, yaitu : Kurang, Cukup, dan Baik

- KetepatanWaktu; terdiri atas 3 himpunan fuzzy, yaitu : Kurang, Cukup, dan Baik

- KesesuaianMateri; terdiri atas 3 himpunan fuzzy, yaitu : Kurang, Cukup, dan Baik

- JumlahSKS; terdiri atas 5 himpunan fuzzy, yaitu : SangatKurang, Kurang,Cukup, Baik dan SangatBaik

\subsubsection{Variabel NilaiAngket}

Untuk mempresentasekan variabel NilaiAngket digunakan kurva berbentuk bahu ( untuk himpunan fuzzy Kurang dan Baik) dan kurva segitiga ( untuk himpunan fuzzy Cukup), seperti terlihat pada gambar 3.2, dan fungsi keanggotaan NilaiAngketMatlab Toolbox terlihat pada gambar 3.3.

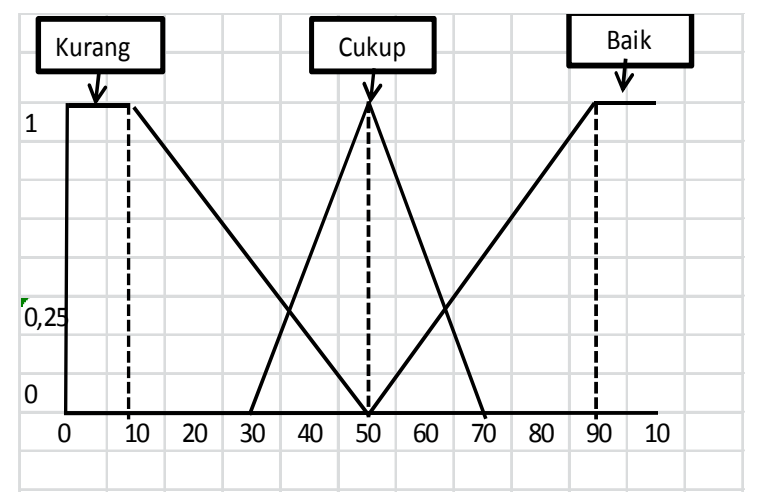

Gambar 3.2. Representase variabel NilaiAngket

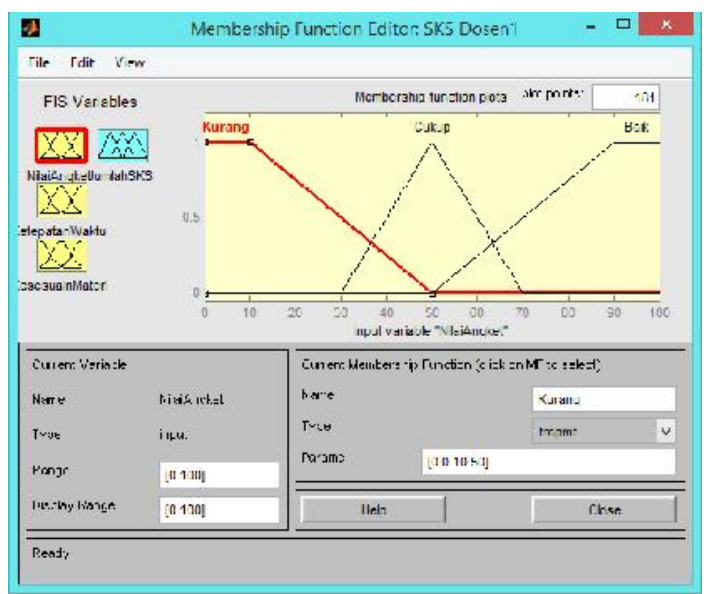

Gambar 3.3. Implementasi NilaiAngket menggunakan Matlab Toolbox
Fungsi Keanggotaan :

$\mu_{\text {NilaiAngket Krg }}[x]=\left\{\begin{array}{c}1 ; \mathrm{x} \leq 10 \\ (50-\mathrm{x}) / 40 ; 10 \leq \mathrm{x} \leq 50 \\ 0 ; \mathrm{x} \geq 50\end{array}\right.$

$\mu_{\text {NilaiAngket Ckp }}[x]=\left\{\begin{array}{c}0 ; \mathrm{x} \leq 30 \text { atau } \mathrm{x} \geq 70 \\ (\mathrm{x}-30) / 20 ; 30 \leq \mathrm{x} \leq 50 \\ (70-\mathrm{x}) / 20 ; 50 \leq \mathrm{x} \leq 70\end{array}\right.$

$\mu_{\text {NilaiAngket } B k^{[x]}}=\left\{\begin{array}{c}0 ; \mathrm{x} \leq 50 \\ (\mathrm{x}-50) / 40 ; 50 \leq \mathrm{x} \leq 90 \\ 1 ; \mathrm{x} \geq 90\end{array}\right.$

\subsubsection{Variabel KetepatanWaktu}

Untuk mempresentasekan variabel KetepatanWaktu digunakan kurva berbentuk bahu ( untuk himpunan fuzzy Kurang dan Baik) dan kurva segitiga ( untuk himpunan fuzzy Cukup), seperti terlihat pada gambar 3.4, dan fungsi keanggotaan KetepatanWaktu Matlab Toolbox terlihat pada gambar 3.5.
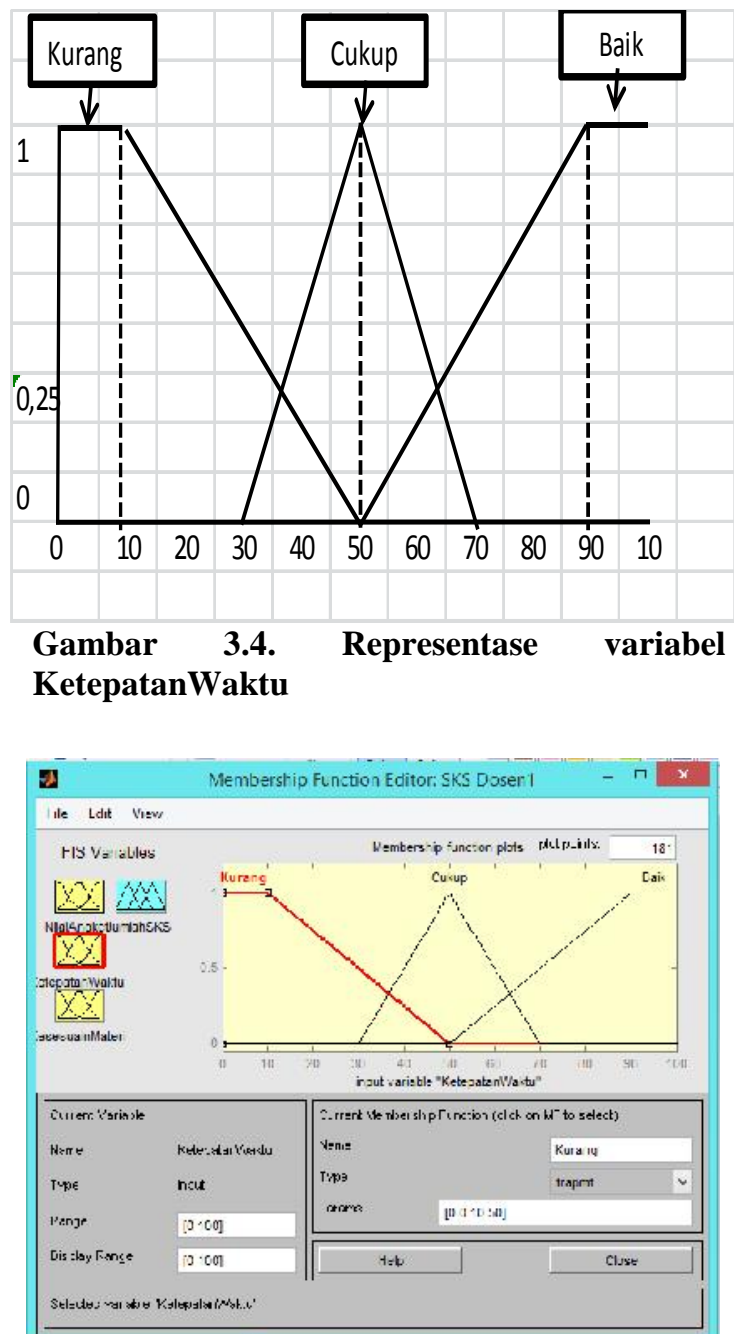

Gambar 3.5. Implementasi KetepatanWaktu menggunakan Matlab Toolbox 
Fungsi Keanggotaan :

$$
\begin{gathered}
\mu_{\text {KetepatanWaktu Krg }}[y]=\left\{\begin{array}{c}
1 ; \mathrm{y} \leq 10 \\
(50-\mathrm{y}) / 40 ; 10 \leq \mathrm{y} \leq 50 \\
0 ; \mathrm{y}>50
\end{array}\right. \\
\mu_{\text {KetepatanWaktu Ckp }[\mathrm{y}]}=\left\{\begin{array}{c}
0 ; \mathrm{y} \leq 30 \text { atau } \mathrm{y} \geq 70 \\
(\mathrm{y}-30) / 20 ; 30 \leq \mathrm{y} \leq 50 \\
(70-\mathrm{y}) / 20 ; 50<\mathrm{y}<70
\end{array}\right. \\
\mu_{\text {KetepatanWaktu Bk }[y]}=\left\{\begin{array}{c}
0 ; \mathrm{y} \leq 50 \\
(\mathrm{y}-50) / 40 ; 50 \leq \mathrm{y} \leq 90 \\
1 ; \mathrm{y}>90
\end{array}\right.
\end{gathered}
$$

\subsubsection{Variabel KesesuaianMateri}

Untuk mempresentasekan variabel KesesuaianMateri digunakan kurva berbentuk bahu ( untuk himpunan fuzzy Kurang dan Baik) dan kurva segitiga ( untuk himpunan fuzzy Cukup), seperti terlihat pada gambar 3.6, dan fungsi keanggotaan KesesuaianMateri Matlab Toolbox terlihat pada gambar 3.7.

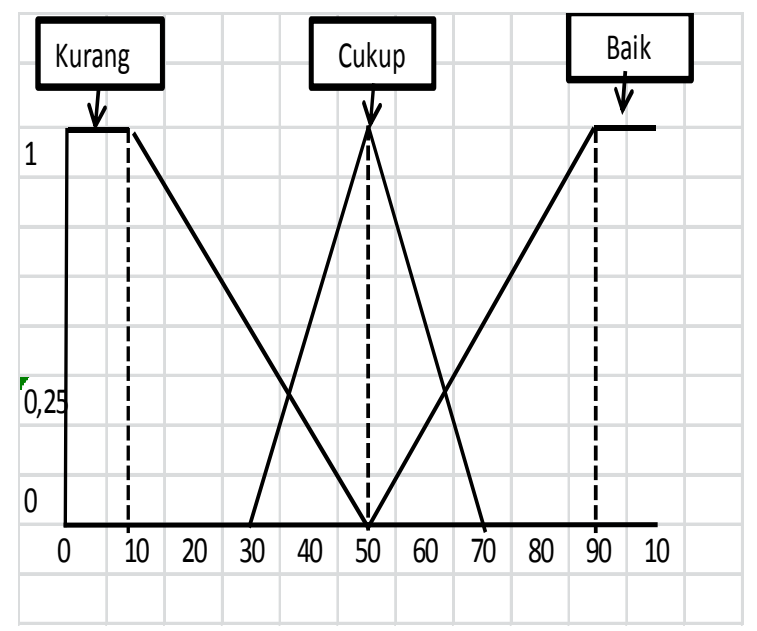

Gambar 3.6. Representase variabel KesesuaianMateri

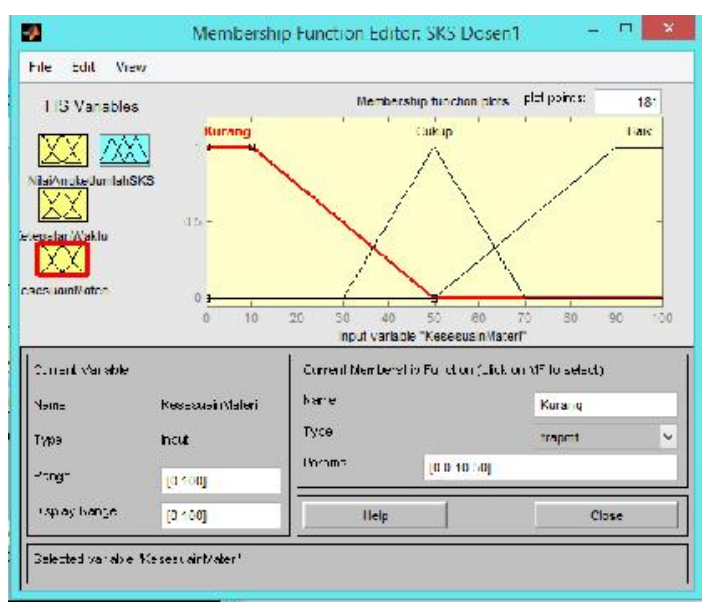

Gambar 3.7. Implementasi KesesuaianMateri menggunakan Matlab Toolbox
Fungsi Keanggotaan :

$$
\begin{gathered}
\mu_{\text {KesesuaianMateri Krg }}[\mathrm{z}]=\left\{\begin{array}{c}
1 ; \mathrm{z} \leq 10 \\
(50-\mathrm{z}) / 40 ; 10 \leq \mathrm{z} \leq 50 \\
0 ; \mathrm{z}>50
\end{array}\right. \\
\mu_{\text {KesesuaianMateri Ck }}[\mathrm{z}]=\left\{\begin{array}{c}
0 ; \mathrm{z} \leq 30 \text { atau } \mathrm{z} \geq 70 \\
(\mathrm{z}-30) / 20 ; 30 \leq \mathrm{z} \leq 50 \\
(70-\mathrm{z}) / 20 ; 50 \leq \mathrm{z} \leq 70
\end{array}\right. \\
\mu_{\text {KesesuaianMateri Bk }^{[\mathrm{z}]}}=\left\{\begin{array}{r}
0 ; \mathrm{z} \leq 50 \\
(\mathrm{z}-50) / 40 ; 50 \leq \mathrm{z} \leq 90 \\
1 ; \mathrm{z}>90
\end{array}\right.
\end{gathered}
$$

\subsubsection{Variabel JumlahSKS}

Untuk mempresentasekan variabel JumlahSKS digunakan kurva berbentuk bahu ( untuk himpunan fuzzy SangatKurang dan SangatBaik) dan kurva segitiga ( untuk himpunan fuzzy Kurang,Cukup, dan Baik), seperti terlihat pada gambar 3.8, dan fungsi keanggotaan JumlahSKS Matlab Toolbox terlihat pada gambar 3.9 .

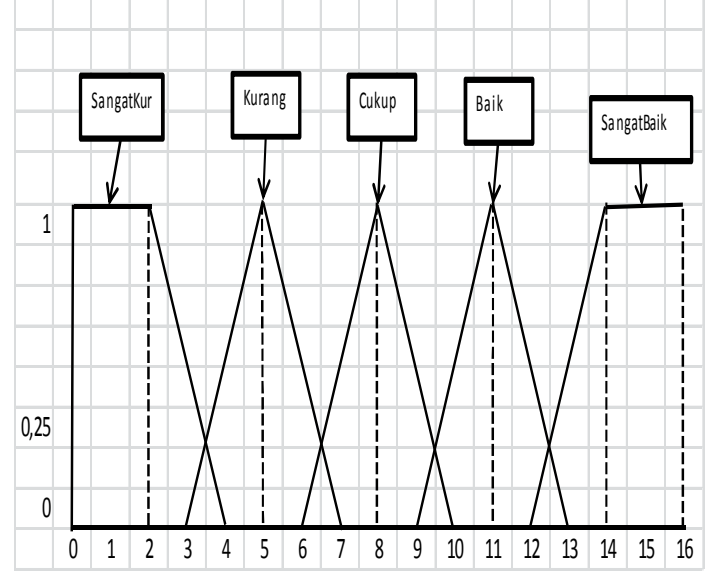

\section{Gambar 3.8. Representase variabel JumlahSKS}

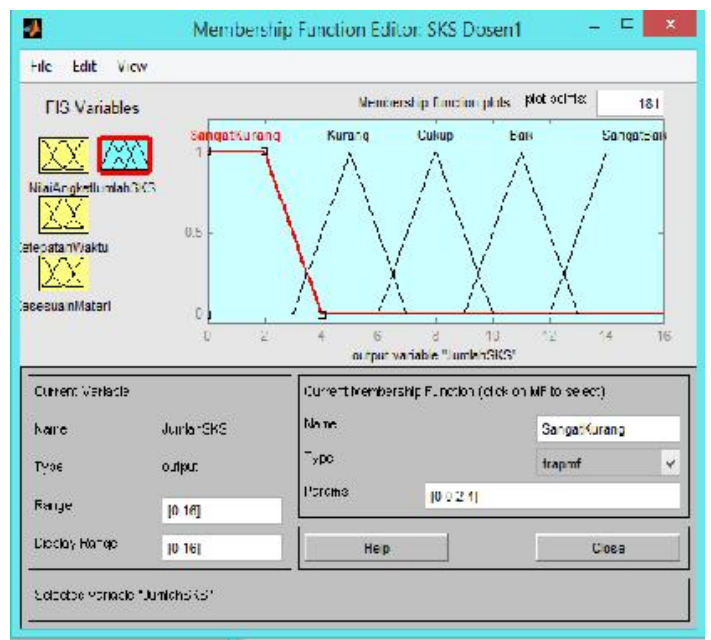

Gambar 3.9. Implementasi JumlahSKS menggunakan Matlab Toolbox 
Fungsi Keanggotaan :

$$
\begin{gathered}
\mu_{\text {JumlahsKS SgtKrg }}^{[\alpha]}=\left\{\begin{array}{c}
1 ; \alpha \leq 2 \\
(4-\alpha) / 2 ; 2 \leq \alpha \leq 4 \\
0 ; \alpha \geq 4
\end{array}\right. \\
\mu_{\text {JumlahSKSKrg }}[\alpha]= \\
\left\{\begin{array}{c}
0 ; \alpha \leq 3 \text { atau } \alpha \geq 7 \\
(\alpha-3) ; 2 ; 3 \leq \alpha \leq 5 \\
(7-\alpha) ; 2 ; 5 \leq \alpha \leq 7
\end{array}\right.
\end{gathered}
$$$$
\mu_{\text {JumlahsKS Ckp }}[\alpha]=\left\{\begin{array}{c}
0 ; \alpha \leq 6 \text { atau } \alpha \geq 10 \\
(\alpha-6) / 2 ; 6 \leq \alpha \leq 8 \\
(10-\alpha) / 2 ; 8 \leq \alpha \leq 10
\end{array}\right.
$$$$
\mu_{\text {IumlahsKS Bk }}[\alpha]=\left\{\begin{array}{c}
0 ; \alpha \leq 9 \text { atau } \alpha \geq 13 \\
(\alpha-9) / 2 ; 9 \leq \alpha \leq 11 \\
(13-\alpha) / 2 ; 11 \leq \alpha \leq 13
\end{array}\right.
$$$$
\mu_{\text {JumlahSKS SgtBkk }}[\alpha]=\left\{\begin{array}{c}
0 ; \alpha \leq 12 \\
(\alpha-12) / 2 ; 12 \leq \alpha \leq 14 \\
1 ; \alpha>14
\end{array}\right.
$$

\subsection{Aplikasi Operator Fuzzy}

Langkah selanjutnya adalah menentukan aturan Fuzzy, seperti yang diperlihatkan pada gambar 3.10. Ada 7 aturan yang digunakan dengan AND conection, yaitu :

1. If (NilaiAngket is Kurang) and (KetepatanWaktu is Kurang) and (KesesuaianMateri is Kurang) then (JumlahSKS is SanganKurang).

2. If (NilaiAngket is Cukup) and (KetepatanWaktu is Cukup) and (KesesuaianMateri is Cukup) then (JumlahSKS is Cukup).

3. If (NilaiAngket is Baik) and (KetepatanWaktu is Baik) and (KesesuaianMateri is Baik) then (JumlahSKS is SangagatBaik).

4. If (NilaiAngket is Kurang) and (KetepatanWaktu is Cukup) and (KesesuaianMateri is Kurang) then (JumlahSKS is SanganKurang).

5. If (NilaiAngket is Baik) and (KetepatanWaktu is Cukup) and (KesesuaianMateri is Baik) then (JumlahSKS is SanganBaik).

6. If (NilaiAngket is Kurang) and (KetepatanWaktu is Cukup) and (KesesuaianMateri is Baik) then (JumlahSKS is Cukup).

7. If (NilaiAngket is Baik) and (KetepatanWaktu is Cukup) and (KesesuaianMateri is Kurang) then (JumlahSKS is Cukup).

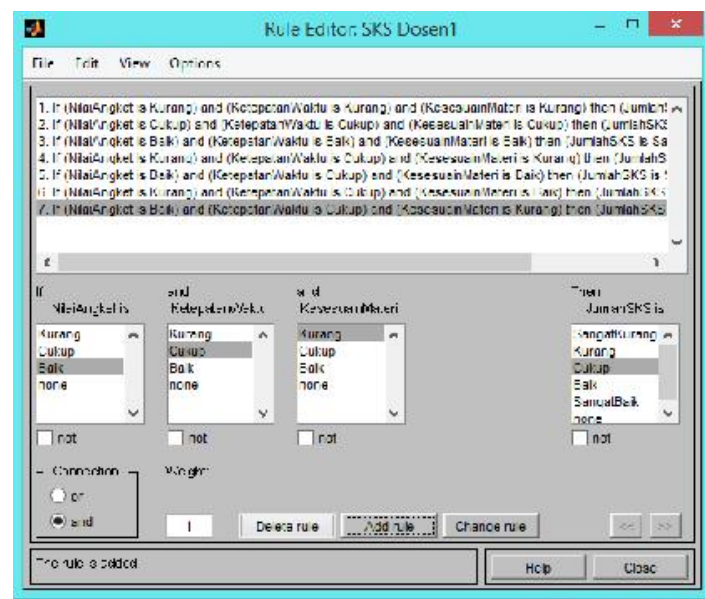

\section{Gambar 3.10. Implementasi Aturan menggunakan Matlab Toolbox}

Setelah dilakukan pemasukan aturan, lalu aplikasi dapat dijalankan, seperti terlihat pada gambar 3.11.

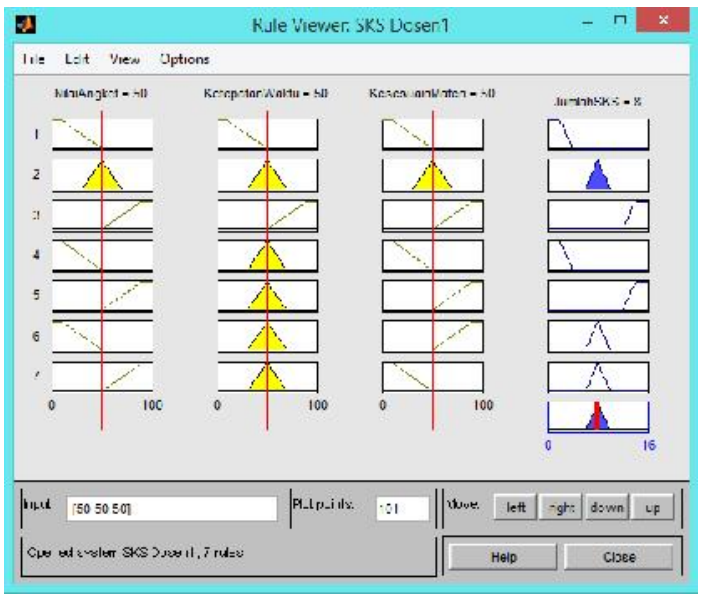

Gambar 3.11. Implementasi Penggunaan aplikasi menggunakan Matlab Toolbox

\section{Kesimpulan}

Sistem pendukung keputusan pemberian jumlah sks mengajar ini digunakan sebagai salah satu acuan dalam pengambilan keputusan dalam pemberian jumlah sks yang akan diajarkan oleh dosen Stmik Kaputama pada semester berikutnya berdasarkan input data masing-masing dosen, pada saat implementasi jika diberikan input [30 80 70], maka keputusannya adalah 8 SKS.

\section{Daftar Pustaka}

\section{Journal:}

Syamsul (2012).Rancang bangun sistem pendukung keputusan pembagian beban kerja dosen (bkd) berbasis logika 
fuzzy.Jurnal Litek (ISSN: 1693-8097) Volume 9 Nomor 2, September 2012: hal. 124-132

Angga Permana (2011), Sistem Pendukung Keputusan Dosen Berprestasi Menggunakan Metode Promethee, http://repository.upi.edu/skripsiview.php?no _skr ipsi=10741 diakses tanggal 1 September 2015.

Yuhilda.(2007). Sistem Pendukung Pengambilan Keputusan Penjadwalan Kuliah Berdasarkan Preferensi Kesediaan Waktu Dosen Untuk Mengajar (Studi kasus pada STIE SBIYogyakarta). Tesis tidak dipublikasikan Yogyakarta: Universitas Gadjah Mada

Ranida Pradita dan Nurul Hidayat (2013).Sistem pendukung keputusan pemilihan guru berprestasi menggunakan metode promethee.JURNAL SAINS DAN SENI POMITS Vol. 2, No.1, (2013) 23373520

Syurahbil and Noraziah Ahmad(2009).Intrusion Preventing System using Intrusion Detection System Decision Tree Data Mining. American Journal of Engineering And Applied Sciences. Vol 2, No.4, pp.721-725.

\section{Book:}

Masafumi Hagiwara(2003).Neuro-FuzzyGA, cetakan ke-9.Sangyotosho.

Takagi, T. and Sugeno, Kang (1985).Fuzzy identification of systems and its applications to modeling and control.IEEE Transactions on Systems, Man and Cybernetics. 15:116132

Zadeh, L. A. (1965). Fuzzy sets. Information and Control, 8:338-353

Turban, E (1995). Decicion Support System And Expert System, Prentice Hall International, United State. 